UDC 669. 14.018.8:621.9.011:538. 21

621. 778

\title{
快削電磁ステンレスの特性に およぼす引抜加工の影響
}

\author{
加: 藤 哲 男* 関 尾 勲**
}

\author{
Influence of Cold Drawing on the Properties of \\ Free-machining Magnetic Core Stainless Steel
}

Tetsuo Katô and Isao Sekio.

\begin{abstract}
Sy nopsis
A study has been made about the variation of properties of free-machining magnetic core stainless steel by drawing and subsequent annealing.

The magnetic properties become worse with increasing of drawing ratio, but they are recovered by annealing with progress of recrystallization. The temperature at which the recovery of magnetic properties starts is found to be about $100^{\circ} \mathrm{C}$ higher (about $600^{\circ} \mathrm{C}$ ) than that in the case of free-machining magnetic core iron and $1 \%$ silicon iron. The magnetic properties are, at the drawing ratio of $10-15 \%$, improved largely and 800 or $850^{\circ} \mathrm{C}$ is recommendable as the annealing temperature.

The magnetic properties are generally excellent by aluminum addition. Even in $900^{\circ} \mathrm{C}$ annealing, there is not any formation of $\gamma$ phase and no deterioration of magnetic properties can be seen.
\end{abstract}

1. 緒帚

電磁バルブを始めとする各種リレーの鉄心材料とし て，耐食性のすぐれた軟質磁性材料が広く使われるよ 5になっている。要求される性質としては, 保磁力が 低く透磁率が高いこと，䬶和磁気す高いことと耐食性 にすぐれていることであるが，これに適合する材料と して、フェライト系ステンレス鋥が挙げられる。フェ ライト系ステンレス鋼の磁性はその種類によって大き く変動する1) 3;がこれまで市販のこの種の材料とし ては低炭素の13\%クロムステンレス鋼が標準になって いるよ 5 である。

これに対し，さきに快削性を付与しむな磁性の向

昭和46年 6 月 22 日受付

*大同製鋼中央研究所, 工博

**大同製鋼中央研究所
上をはかる5) 研究を行なったが，その結果実用試験も 重ねて被削性，耐食性ととるに十分磁性のすぐれた材 料を開発することができた。この快削電磁ステンレス の使用例については後記するが，材料は引抜加工のミ ガキ棒状態で使用されることが少なくない。そのため 引抜加工によって生ずる特性変化の状況について調查 し，この材料の製造扰よび使用上の資料を求めること とした。ここに試験結果をとりまとめて報告する。

\section{2. 使用例}

二つの使用例について説明する。

用途としては電磁バルブが最も多く，構造は多種に わたっているが,その5ち三方㚏の製品例をPhoto. 1 に示す。Fig. 1 はその作動状態をあらわす断面図を 示す。3 部分に快削電磁ステンレスが使われている。 図において aおよびbの部分は固定であるが，c の部 分は可動になっている。左図は励磁コイルに電流を通 


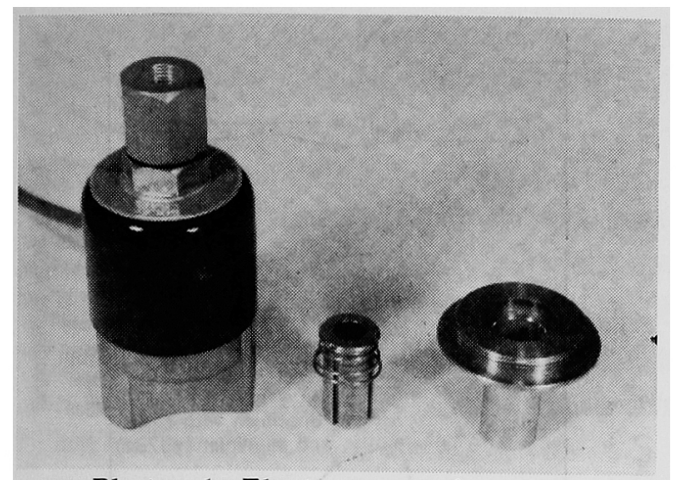

Photo. 1. Electromagnetic valve.

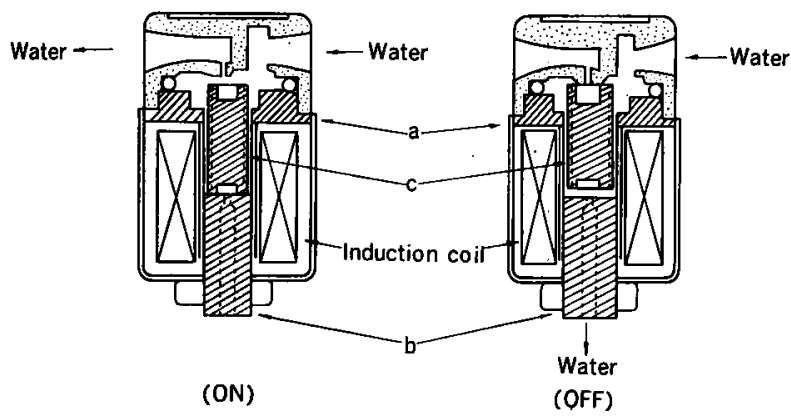

Fig. 1. Schematic diagram of the electromagnetic valve.

じ可動部分 $\mathbf{c} か \mathbf{b}$ の側に吸引された状態を示してい る。このときバルブは図の左右方向に液体が流通す る。右図は電流を切り可動部分がばねにより押し上げ られた状態を示す。このときは液体は $\mathrm{c}$ 部分の間を抜 けて右から下方へ流通するよ5になっている。

Fig. 2 は電池式チャイムの構造の 概略図を示す。 可動鉄心に細い丸棒状の快削電磁ステンレスが使われ

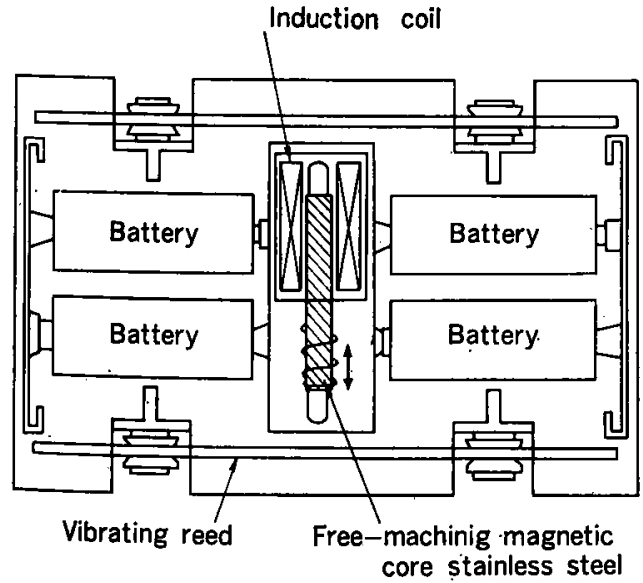

Fig. 2. Schematic diagram of the chime.
ている。ボタンスイッチにより励磁コイルに電流が通 じると可動鉄心は図の左方に吸引されて左側の振動片 をたたく。電流が切られるとばねによりるどされて右 側の振動片をたたいて音を出すよ5になっている。

\section{3. 試料および試験方法}

試験は 2 種の成分の材料について行なった。供試材 の化学成分を Table 1 亿示す。Y3733 では土特にア ルミニゥムの添加は行なわず脱酸程度にとどめ，Y 3734 では $0.3 \%$ のアルミニゥム添加をねらって溶解

Table 1. Chemical compositions of specimens $(\%)$

\begin{tabular}{c|c|c|c|c|c}
\hline No. & $\mathrm{C}$ & $\mathrm{Si}$ & $\mathrm{Mn}$ & $\mathrm{P}$ & $\mathrm{S}$ \\
\hline $\mathrm{Y} 3373$ & 0.009 & 0.91 & 0.27 & 0.013 & 0.026 \\
\hline $\mathrm{Y} 3734$ & 0.010 & 0.98 & 0.29 & 0.013 & 0.025 \\
\hline $\mathrm{No}$ & $\mathrm{Cu}$ & $\mathrm{Ni}$ & $\mathrm{Cr}$ & $\mathrm{Al}$ & $\mathrm{Pb}$ \\
\hline $\mathrm{Y} \mathrm{3733}$ & 0.02 & 0.11 & 13.30 & 0.004 & 0.12 \\
\hline $\mathrm{Y} 3734$ & 0.01 & 0.06 & 13.32 & 0.31 & 0.13 \\
\hline
\end{tabular}

し，磁性向上をはかった 導炉によって行ない，2 回の熱間圧延で直径 $16 \mathrm{~mm}$ の丸棒まで加工した。その後直径 $10 \mathrm{~mm}$ となるまで， 引抜加工を行なったが途中に $750^{\circ} \mathrm{C} ， 4$ 時間の中間烤 鈍をはさんで最終泠間加工率が 0 から $30 \%$ まで，段 階的に変化するよ 5 に調整した。焼鈍はすへてて真空中 で行なった。

磁気測定は自記磁束計により継鉄法6)で行なった。 これにより磁化抢よびヒステリシス曲楾を画き，それ より磁束密度 B, 飽和磁気（30エルステッドにおける 磁束密度）Bs，保磁力 Hc を読みとった。また透磁 率曲線を画いて最大透磁率 $\mu_{m}$ を求めた。

機械試験は磁気測定済の試片について5トンフム スラー試験機により行ない引張強さ $\sigma_{\mathrm{B}}, 0.2 \%$ 耐力 $\sigma_{0.2}$, 伸び El および校りRAを測定した。合わせて ブリネル硬さ $\mathrm{H}_{\mathrm{B}}$ を測定し，顕微鏡による組織観察も 行なった。
4. 磁
性

Fig. 3 は2 種の供試材について引抜加工による磁 性変化を測定した結果を示す。Al 添加試料において 総体的に磁性が上回っているが，いずれも5\%から10 


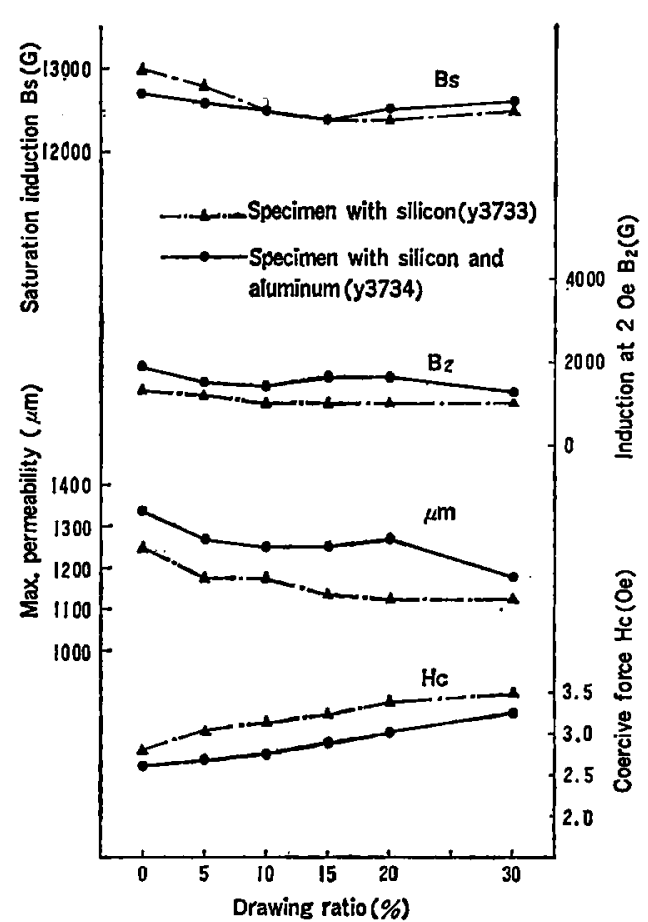

Fig. 3. Influence of drawing ratio on magnetic properties.

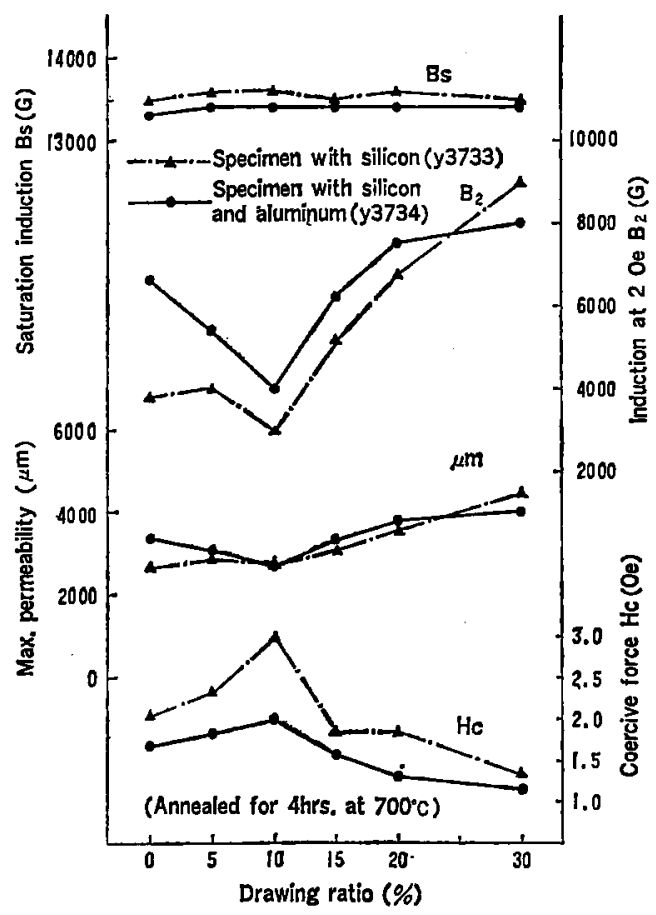

Fig. 4. Relation between magnetic properties after annealing at $700^{\circ} \mathrm{C}$ and predrawing ratio.

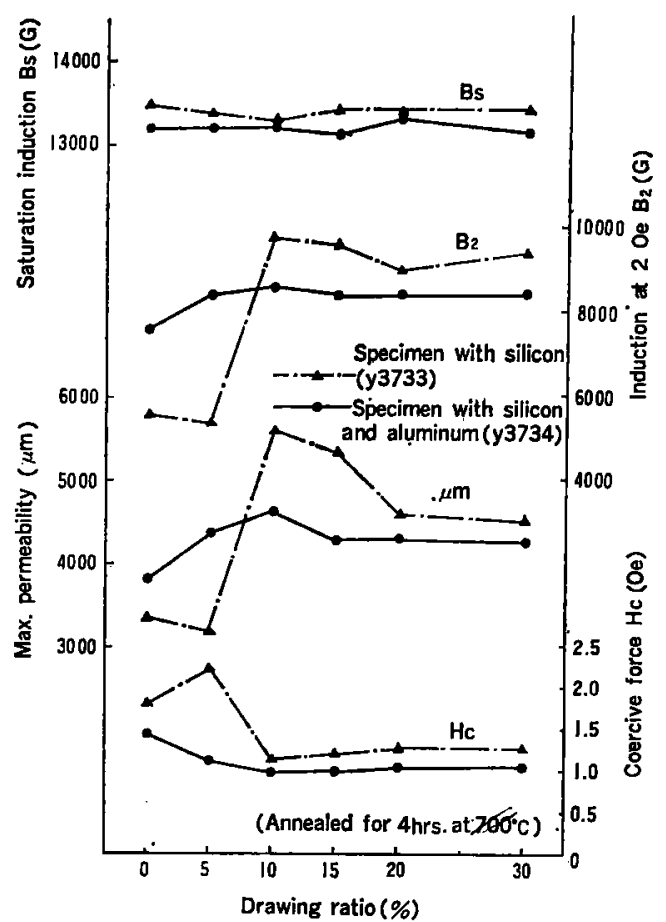

Fig. 5. Relation between magnetic properties after annealing at $800^{\circ} \mathrm{C}$ and predrawing ratio.

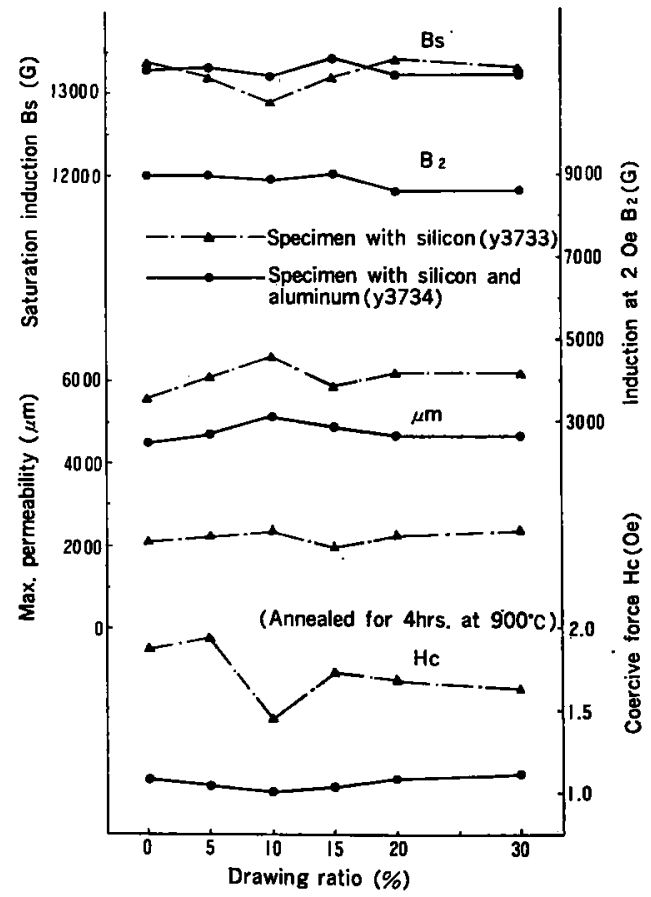

Fig. 6. Relation between magnetic properties after annealing at $900^{\circ} \mathrm{C}$ and predrawing ratio. 
\%程度までの弱加工により Hc は大きく增加し，ま た $\mu_{m}$ と $\mathrm{B}_{2}$ は大きく低下して著しい磁性悪化とな っている。をた，さらに加工率が増加するにしたがっ て少しっつ磁性悪化の傾向となっている。

Fig. 4 は上記の引拔加工後 $700^{\circ} \mathrm{C}$ で 4 時間㜔鈍し たときの磁性について測定した結果を示す。磁性変化 の推移はさきの快削純鉄における実験結果6) と同様の 傾向となっており，15\% 以上の高加工率側で再結晶 にともなろ磁性の回復が見られる。10\% 以下の低加 工盖側では磁性回復は僅かな值にとどまっている。

Fig. 5 扰よび 6 はそれぞれ引抜加工後 $800^{\circ} \mathrm{C}$ およ び $900^{\circ} \mathrm{C}$ で各 4 時間焼鈍したときの磁性について測定 した結果を示す。両者とも各加工率の全般にわたって 磁牲の回復と向上が見られる。焼鈍により結晶が粗大 化し最す $\mathrm{Hc}$ が低く， $\mu_{m}$ が高くなって磁性が向上す る加工率は10ないし 15\% となっている。他の結果 ${ }^{3}$ よりやや低い加工率のところになっているが，快削純 鉄6)扰よび $1 \%$ け素鉄》の結果とはよく合ってい る。この 5 ち $900^{\circ} \mathrm{C}$ 焼鈍についてアルミニウム無添加 試料（Y3733）では磁性が劣化し，アルミニウム添加 試料（Y3734）とくらべ， Hc， $\mu_{m}$ および $\mathrm{B}_{2}$ の間の 差か大きくなった。

Fig. 7 はアルミニウム無添加（Y3733）の試料に ついて焼鈍温度と磁性との関保についてとりまとめた 結果である。引抜加工臽は $0 ， 10$ および $20 \%$ の状態 について示した。烧鈍時間はいずれる 4 㭙間である。 $700^{\circ} \mathrm{C}$ 焼鈍では $10 \%$ 加工にくらべ $20 \%$ 加工後の方 が Hc は低く， $\mu_{n}$ は高くなって磁性がすぐれ強加工 側から再結晶が谁行して磁性回復へ向っていることが わかる。 800 ないし $850^{\circ} \mathrm{C}$ 焼鈍に扰いて $10 \%$ 加工の ところで最も高い磁性となっている。900 $\mathrm{C}$ を越える 焼鈍ではさきに述べた通りそれより磁性が悪化してい る。

Fig. 8 はアルミニゥム添加（Y3734）の試料につ いて同様に焼鈍温度と磁性との関保についてとりまと めた結果を示す。低温側での磁性変化の傾向は前の試 料と活活同様であり $10 \%$ 加工後の 800 ないし $850^{\circ} \mathrm{C}$ 焼鈍に扣いて低い Hc と高い $\mu_{m}$ が得られ最も高い 磁性となっている。Hc は 1.0 エルステッドを割るよ 万になっている。その後 $900^{\circ} \mathrm{C}$ 燒鈍を越えてる特に磁 性の劣化は見られず，加工率 0 のときの磁性は向上し て全体の磁性が近ずくよ5になっている。

以上の試験結果から明らかなよ 5 K，Y 3734 試料 は加工および烧鈍した状態の全般にわたって磁性がす ぐれていることが確認された。工業的に快削電磁ステ

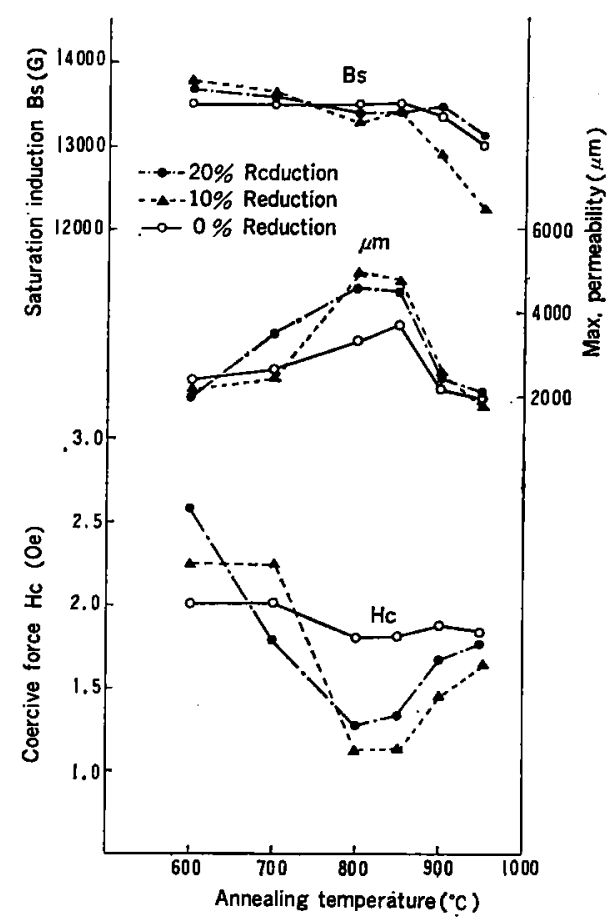

Fig. 7. Effects of annealing temperature on the magnetic properties of the specimen with silicon (Y3733) after drawing.

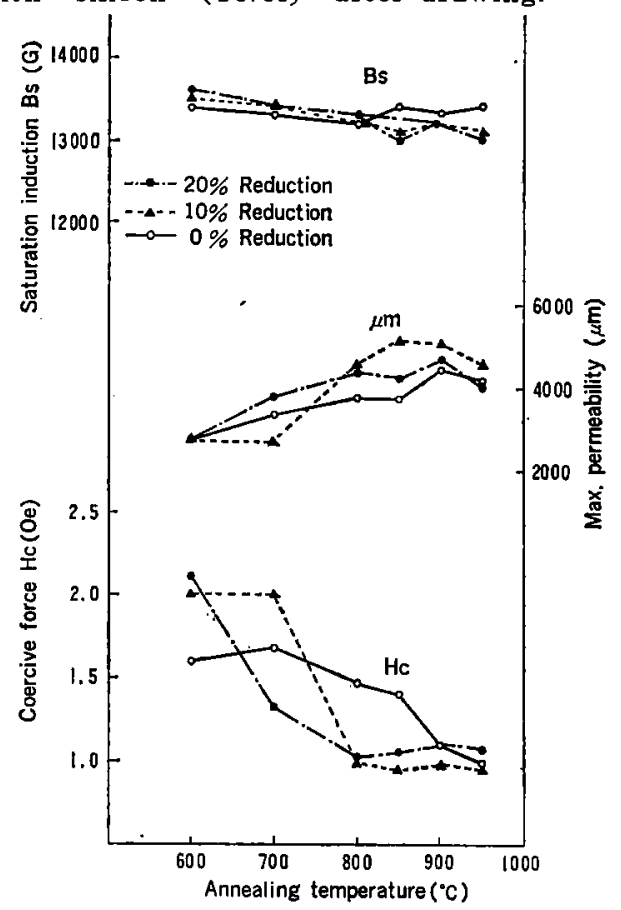

Fig. 8. Effects of annealing temperature on the magnetic properties of the specimen with silicon and aluminum (Y3734) after drawing. 


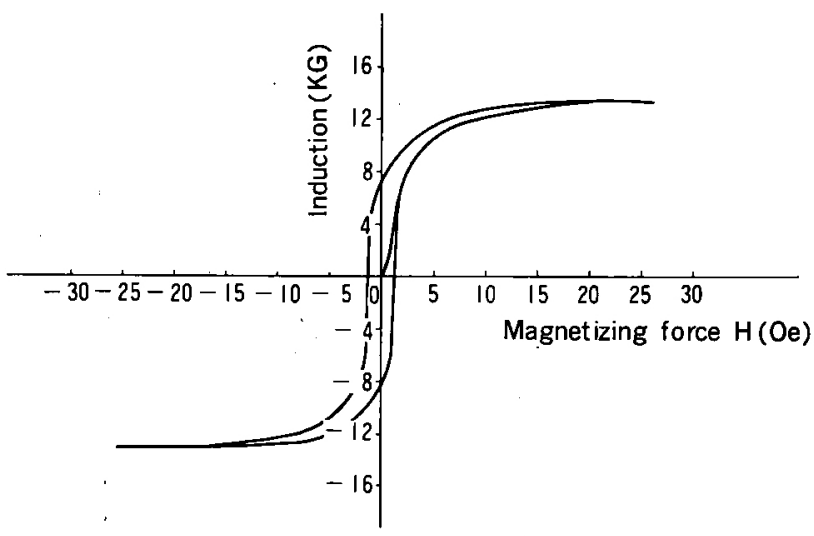

Fig. 9. Magnetization and hysteresis curves of specimen drawed at $10 \%$ reduction and annealed at $850^{\circ} \mathrm{C}$.

ンレスの標準成分はこの化学成分を目標とすることに している。

Fig. 9 は本試験で達せられた最む良い状態のヒス テリシス打よび透磁率曲線を示す。引抜加工率10\%， 焼鈍条件 $850^{\circ} \mathrm{C} ， 4$ 時間, $\mathrm{Hc} 1.0$ エルステッド， $\mu_{m}$ $5040, \mathrm{Br} 8400$ ガウス, B 8800 ガウス, Bs 13100 ガウスである。

\section{5. 诘晶 粒 度}

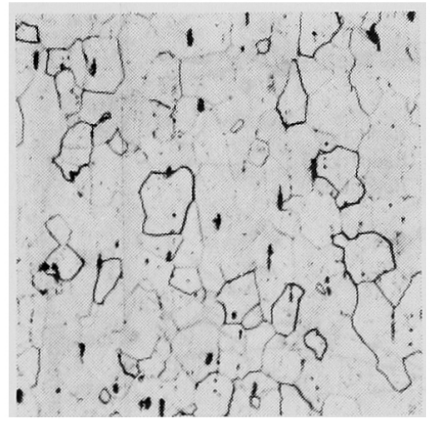

(a) $0 \%$ Red.

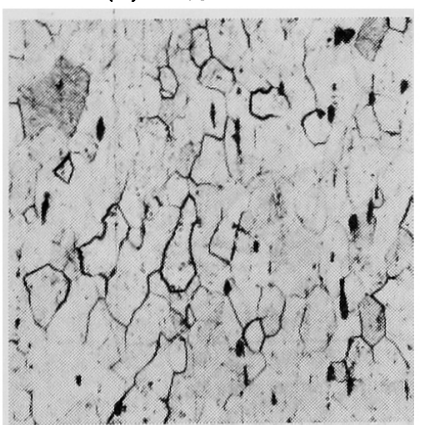

(d) $15 \%$ Red.

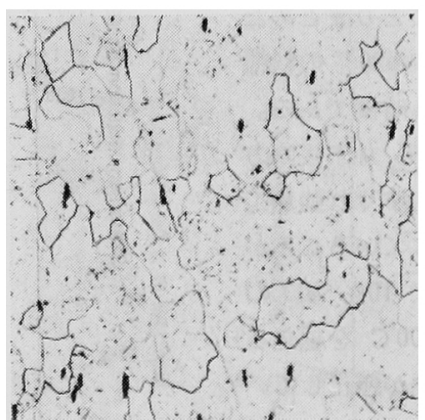

(b) $5 \%$ Red.

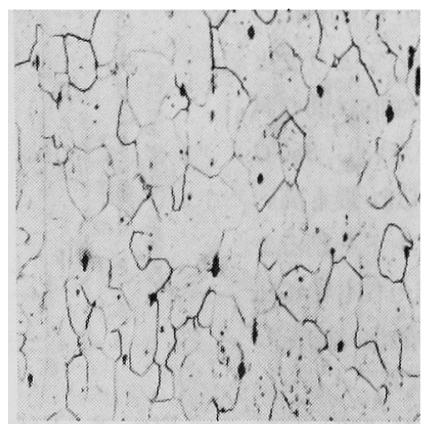

(e) $20 \%$ Red.

Photo. 2，3 に引抜加工した状態 で観察 した顕微鏡組織写真を示す。倍率は以下すべ て 150 倍で使用した。腐蝕液はビレラであ る。両材料とも加工率の增加炕ともない, 引 抜方向に結晶がのびているのが見られる。

Photo.4，5 は各加工率の引报加工後 700 ${ }^{\circ} \mathrm{C} て ゙ 4$ 時間烍鈍した状態について観察した影 微鏡組織写真を示す。 $600^{\circ} \mathrm{C}$ 焼鈍ではまだ加 工の影響か残り明らかな再結晶の進行は見ら れないか，この $700^{\circ} \mathrm{C}$ になると両材料とる15 \%以上の加工率のところで再結晶がすすんで いる。磁性変化がこの再結晶汇明らかに依存 していることがわかる。

Photo.6, 7 は各加工率の引拔加工後 800 ${ }^{\circ} \mathrm{C} て ゙ 4$ 時間烧鈍した状態について観察した顕微鏡組織 写真を示す。全般にわたって再結晶がすすみ両材料 とも特に10扩よび 15\% 加工のところで結晶が粗大化 している。 $850^{\circ} \mathrm{C}$ 焼鈍のときの組織写真はここに示さ ないが，さらに再結晶はすすみ， $5 \%$ 加工のところ でも粗大化するようになっている。フルミニゥム添加 （Y3734）および無添加（Y3733）の試料を比較する 々前者に打いて粗大化の傾向が強く，これが磁性向上 につながっていることが知られる。

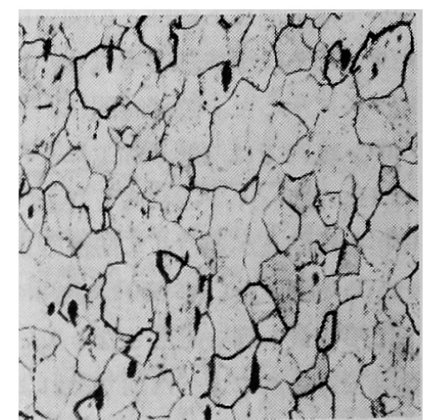

(c) $10 \%$ Red.

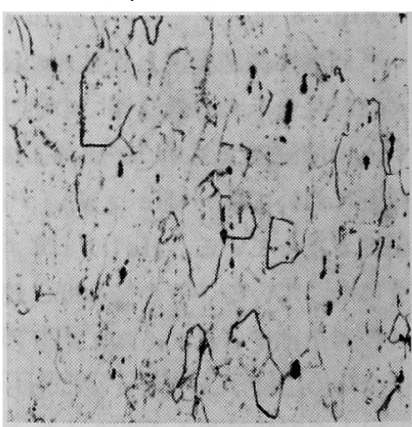

(f) $30 \%$ Red.

Photo. 2. Microstructures of the specimen with silicon (Y3733) after drawing at various reductions. $(\times 150)$ 


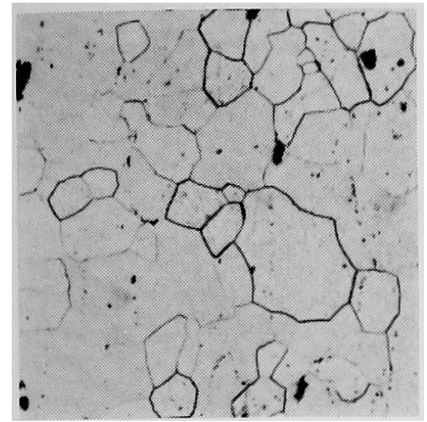

(a) $0 \%$ Red.

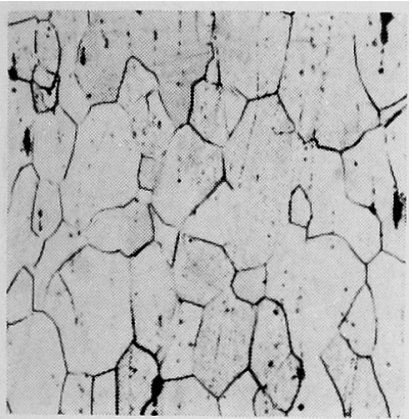

(d) $15 \%$ Red.

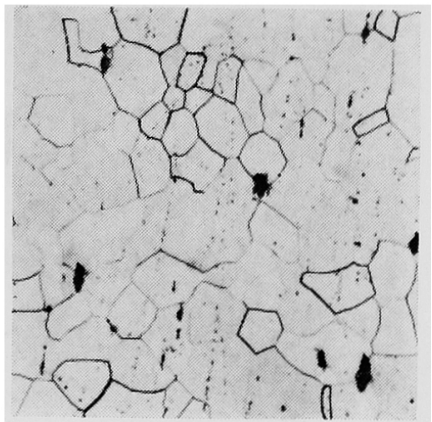

(b) $5 \%$ Red.

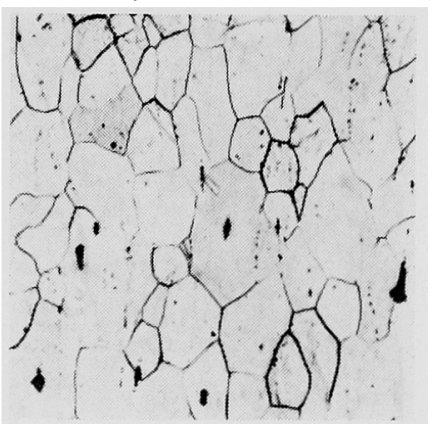

(e) $20 \%$ Red.

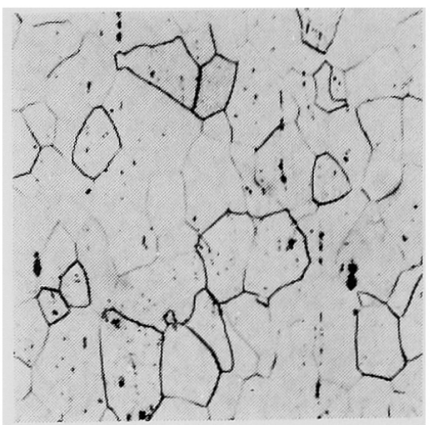

(c) $10 \%$ Red.

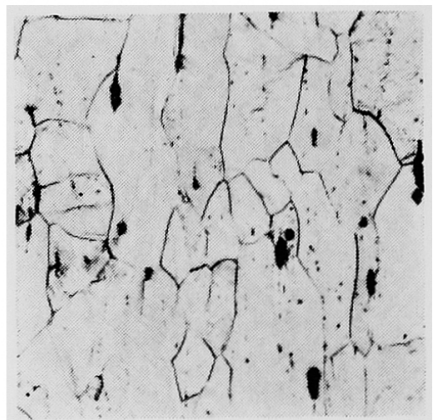

(f) $30 \%$ Red.

Photo. 3. Microstructures of the specimen with silicon and aluminum (Y3734) after drawing at various reductions. $(\times 150)$

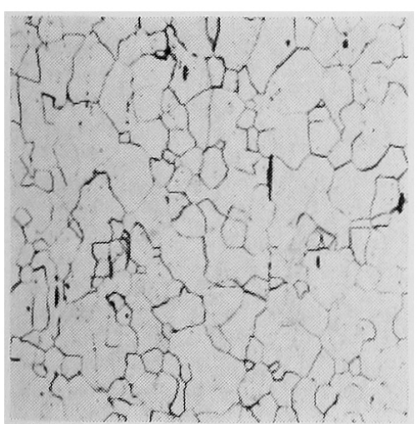

(a) $0 \%$ Red.

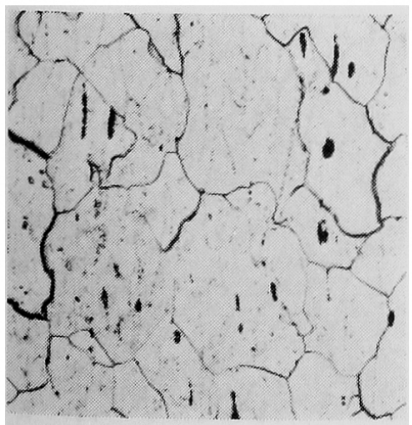

(d) $15 \%$ Red.

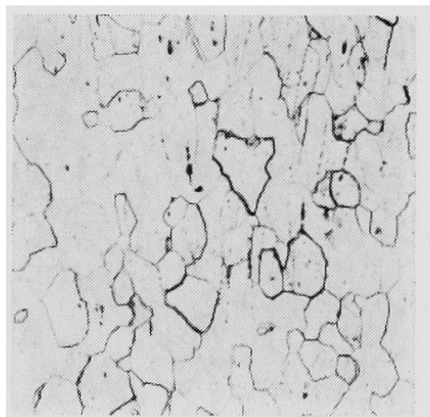

(b) $5 \% \mathrm{Red}$.

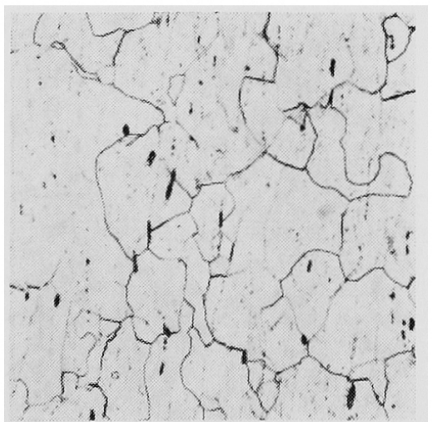

(e) $20 \%$ Red.

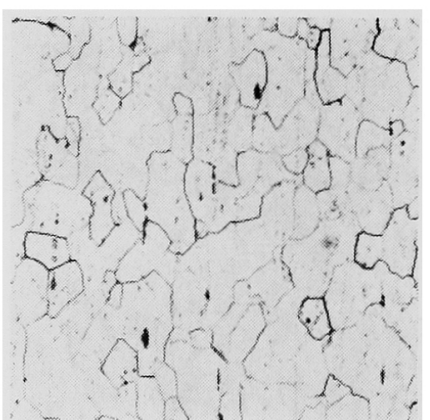

(c) 10\% Red.

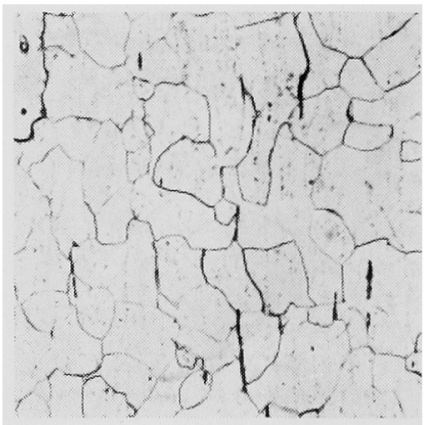

(f) $30 \%$ Red.

Photo. 4. Microstructures of the specimen with silicon (Y3733) after drawing at various reductions and subsequent annealing at $700^{\circ} \mathrm{C} .(\times 150)$ 


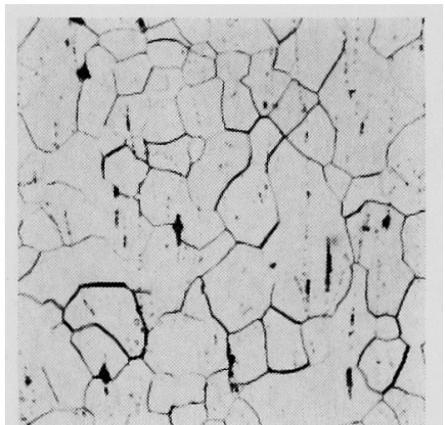

(a) $0 \% \mathrm{Red}$.

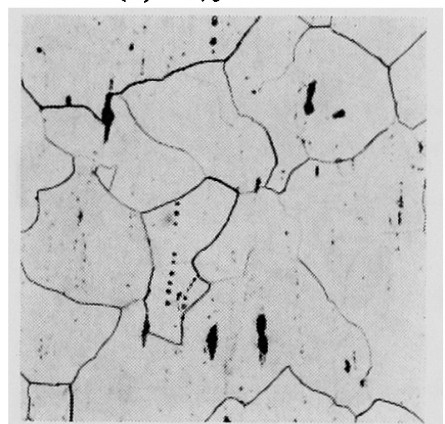

(d) $15 \%$ Red.

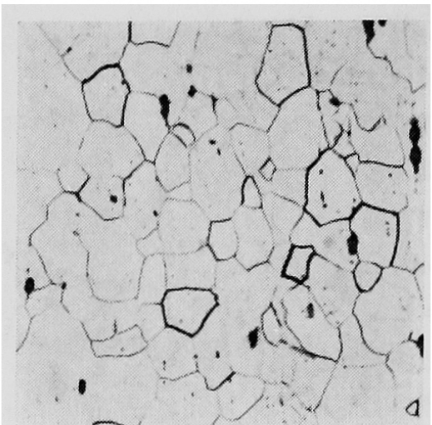

(b) $5 \%$ Red.

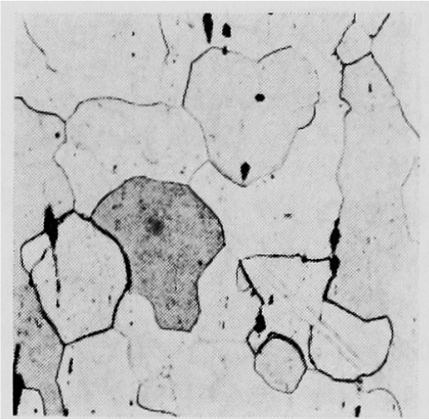

(e) $20 \%$ Red.

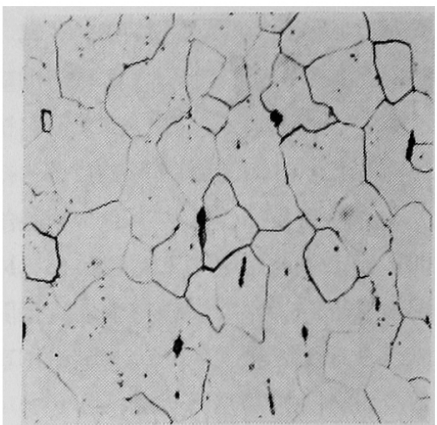

(c) 10\% Red.

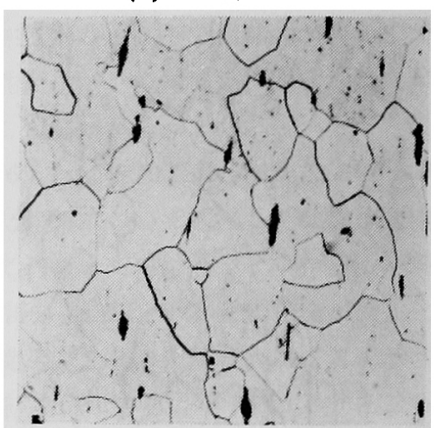

(f) $30 \%$ Red.

Photo. 5. Microstructures of the specimen with silicon and aluminum (Y3734) after drawing at various reductions and subsequent annealing at $700^{\circ} \mathrm{C} .(\times 150)$

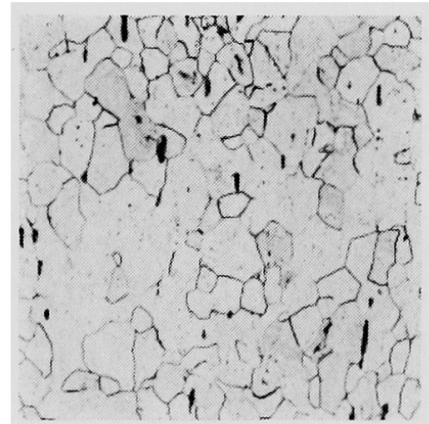

(a) $0 \%$ Red.

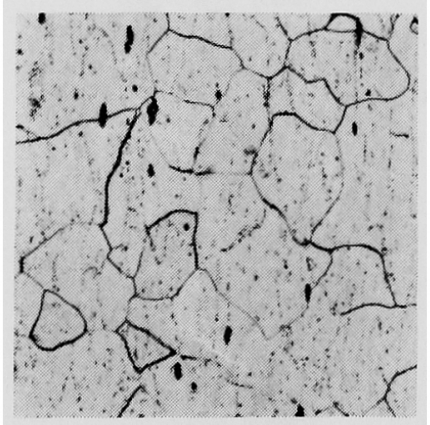

(d) $15 \%$ Red.

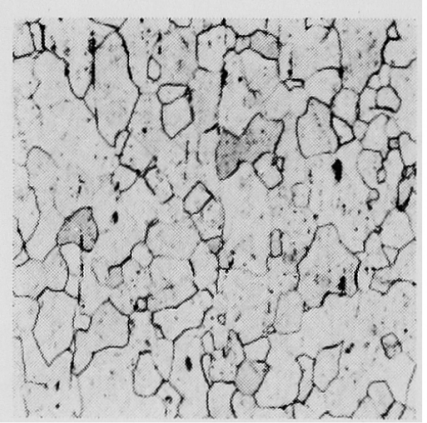

(b) 5:ó Red.

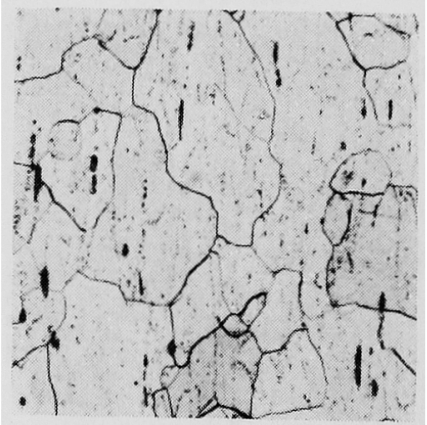

(e) $20 \%$ Red.

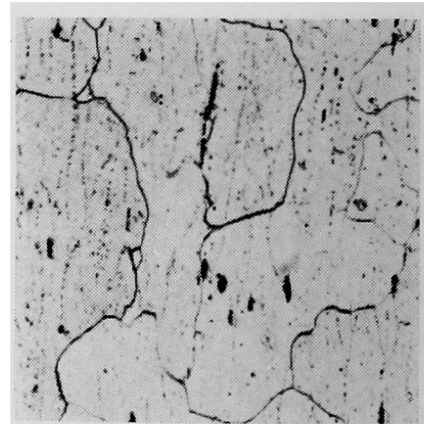

(c) $10 \%$ Red.

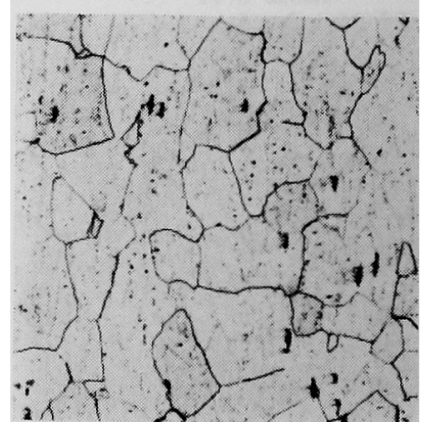

(f) $30 \%$ Red.

Photo. 6. Microstructures of the specimen with silicon (Y3733) after drawing at various reductions and subsequent annealing at $800^{\circ} \mathrm{C} .(\times 150)$ 


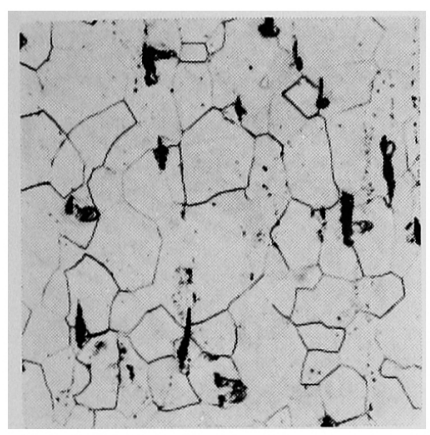

(a) $0 \%$ Red.

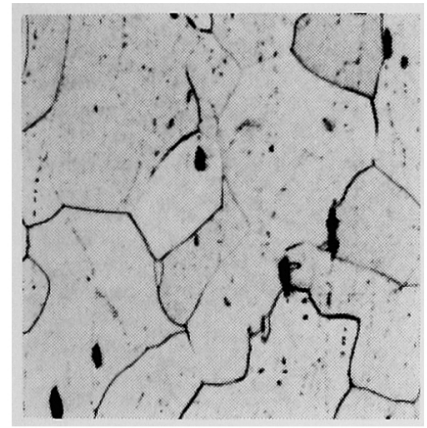

(d) $15 \%$ Red.

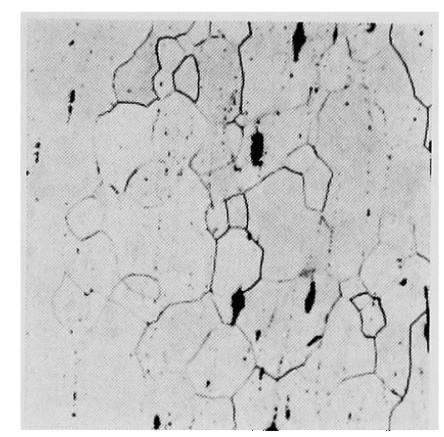

(b) $5 \%$ Red.

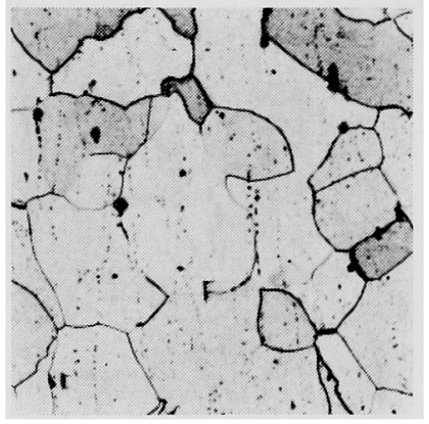

(e) $20 \%$ Red.

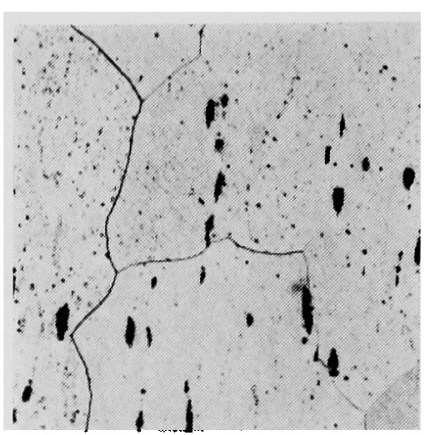

(c) $10 \%$ Red.

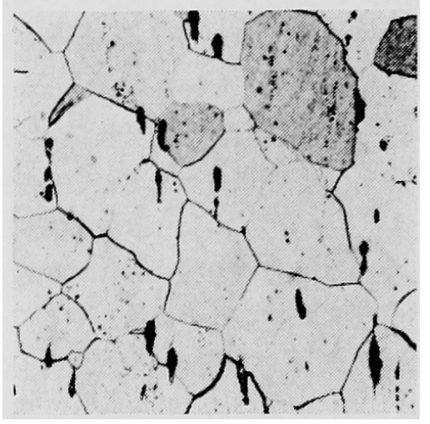

(f) $30 \%$ Red.

Photo. 7. Microstructures of the specimen with silicon and aluminum (Y3734) after drawing at various reductions and subsequent annealing at $800^{\circ} \mathrm{C}(\times 150)$

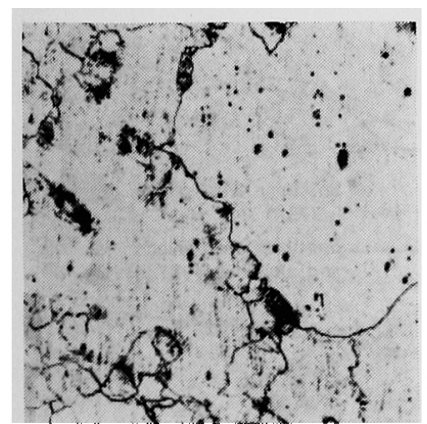

(a) $0 \%$ Red.

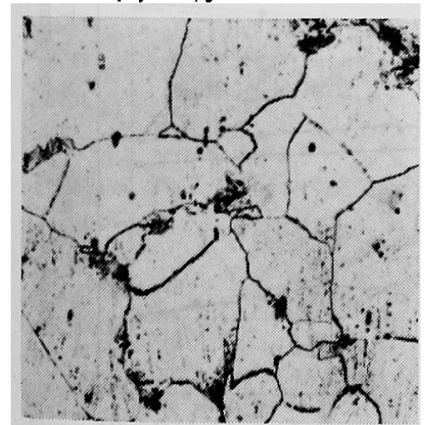

(d) $15 \%$ Red.

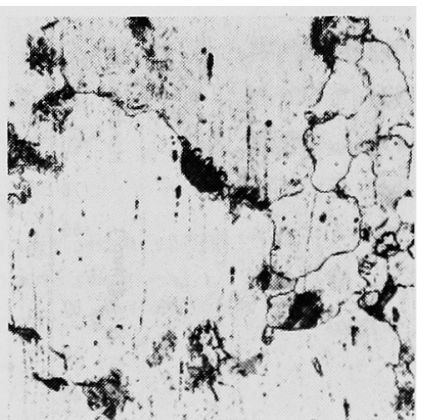

(b) $5 \%$ Red.

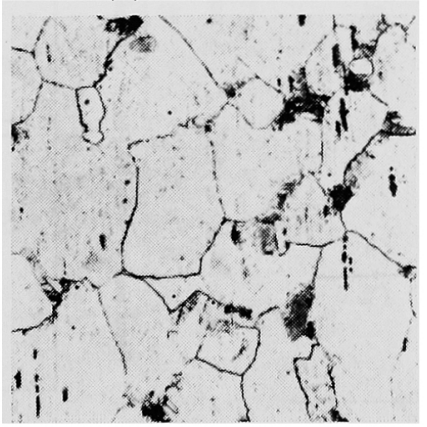

(e) $20 \%$ Red.

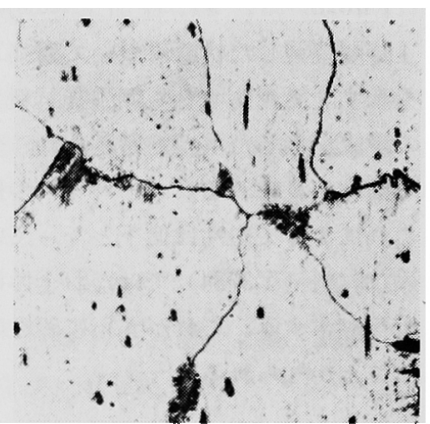

(c) $10 \%$ Red.

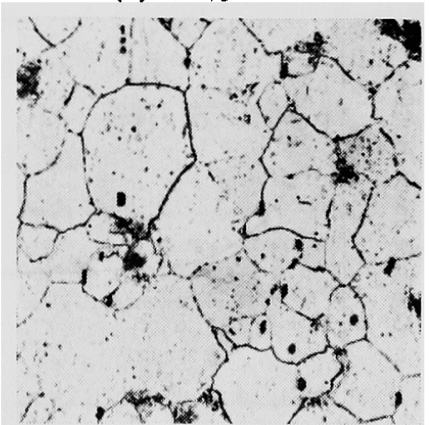

(f) $30 \%$ Red.

Photo. 8. Microstructures of the specimen with silicon (Y3733) after drawing at various reductions and subsequent annealing at $900^{\circ} \mathrm{C} .(\times 150)$ 


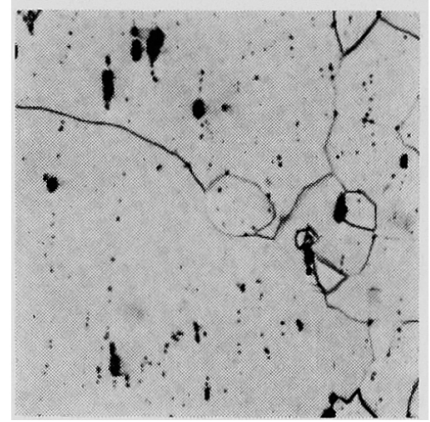

(a) $0 \%$ Red.

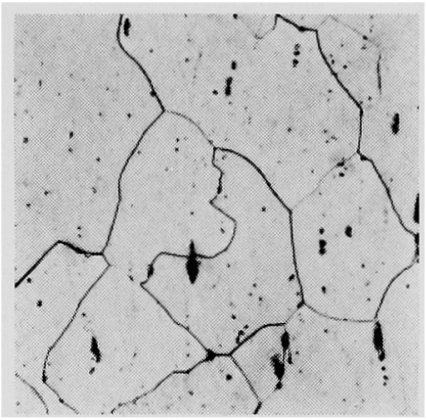

(d) $15 \%$ Red.

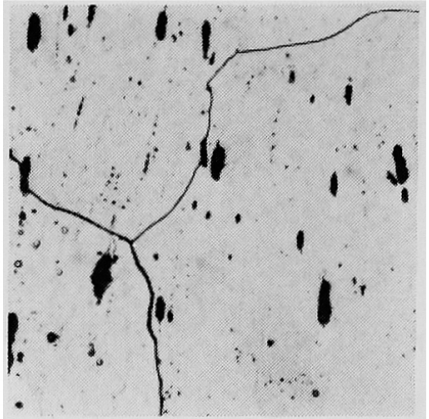

(b) $5 \%$ Red.

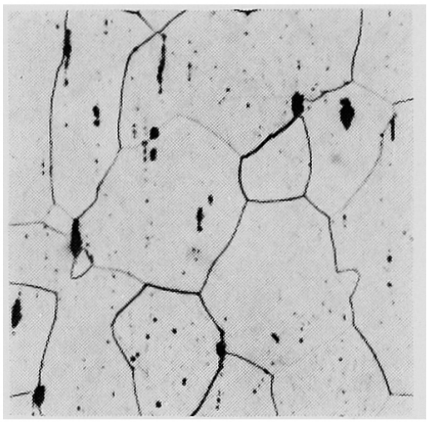

(e) $20 \%$ Red.

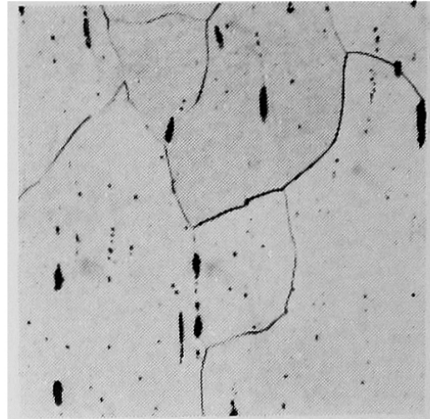

(c) $10 \%$ Red.

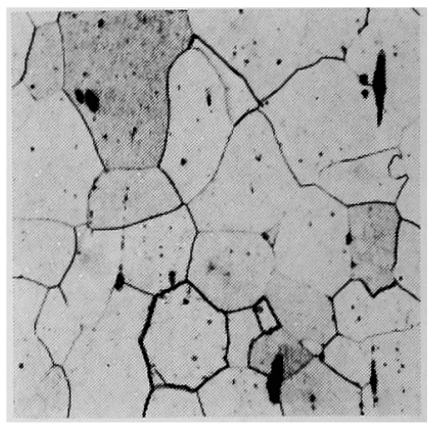

(f) $30 \%$ Red.

Photo. 9. Microstructures of the specimen with silicon and aluminum (Y3734) after drawing at various reductions and subsequent annealing at $900^{\circ} \mathrm{C} .(\times 150)$

Photo. 8，9は各加工率の引抜加工後 $900^{\circ} \mathrm{C}$ で 4 時間焼鈍した状態について観察した顕微鏡組織写真 を示す。アルミニウム無添加試料（Y3733）では $r$ 相 の生成が生じたものと考光られ，全体にわたって混粒 の傾向が見られる。カーバイドの偏析る起っている。 これによって磁性は低下となっている。アルミニゥム 添加試料（Y3734）ではなお全体に再結晶, 結晶の粗 大化がすすみ，これがさらに磁性向上につながってい ることが知られる。

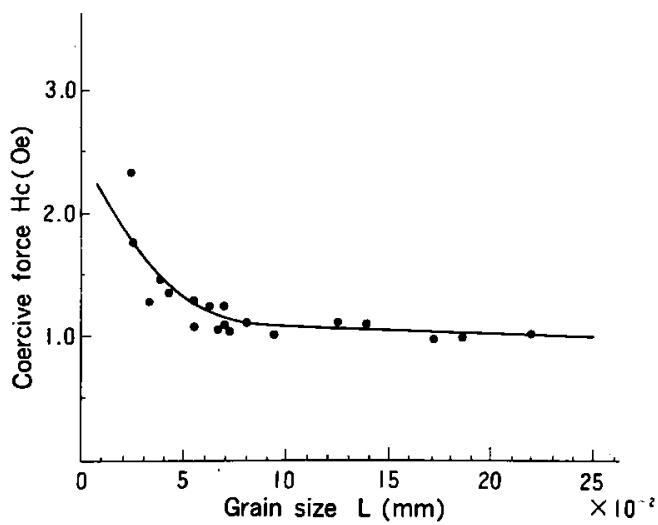

Fig. 10. Relation between grain size and coercive force.

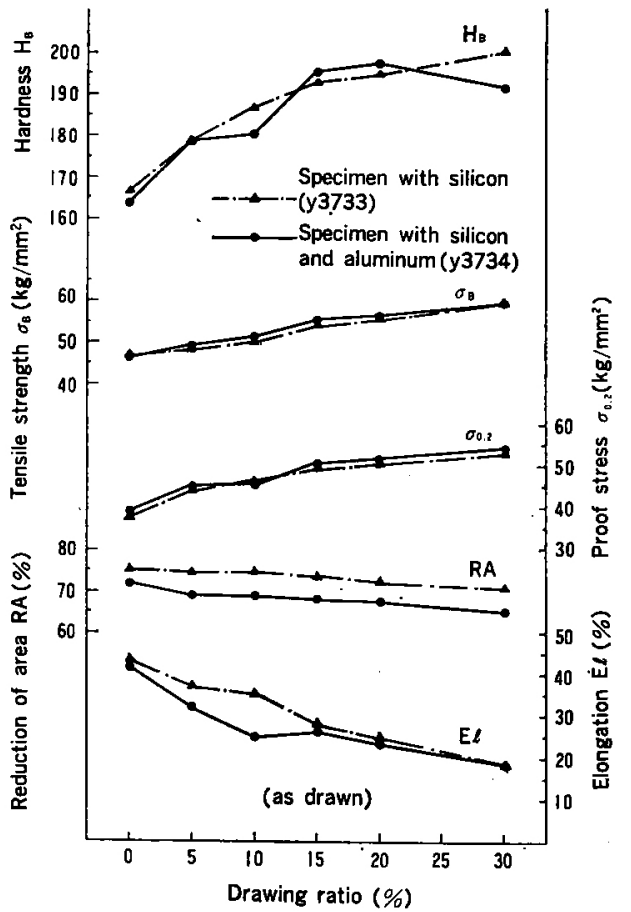

Fig. 11. Influence of drawing ratio on mechanical properties. 
Fig. 10 はこの実験結果から結晶粒度と Hc との 関係を求めた結果を示す。 $\mathrm{Hc}$ と平均粒径Lとの逆数 とは潘比例し，関保式は

$$
\mathrm{Hc}=\frac{1.25}{\mathrm{~L}}+1.00(\mathrm{Oe})
$$

が得られた。

\section{6. 機械的性 页}

Fig. 11 は2 種の供試材について引抜加工による機 㭜的性質の変化を測定した結果を示す。引抜加工率の 堌加にしたがって単調に硬化して $\mathrm{H}_{\mathrm{B}}, \sigma_{\mathrm{B}}$ および $\sigma_{0.2}$ は上昇し， RA および E1 は低下している。

引报加工後の焼鈍に上る機械的性質の変化の傾向は

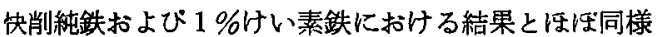
であるが，軟化の進行はやや遅いよ5である。 $600^{\circ} \mathrm{C}$

（4時間）ではまだ引抜加工率により硬化した傾问が 強く残るが， $700^{\circ} \mathrm{C}$ (4 時間)になると，その加工の 影響はほとんど消失している。

Fig. 12 K上記引抜加工後 $800^{\circ} \mathrm{C} て ゙ 4$ 時間焼鈍した ときの機械的性質を示す。低加工率の結晶粗大化した ところでわずかな伸びと絞りの低下が見られる。標洀

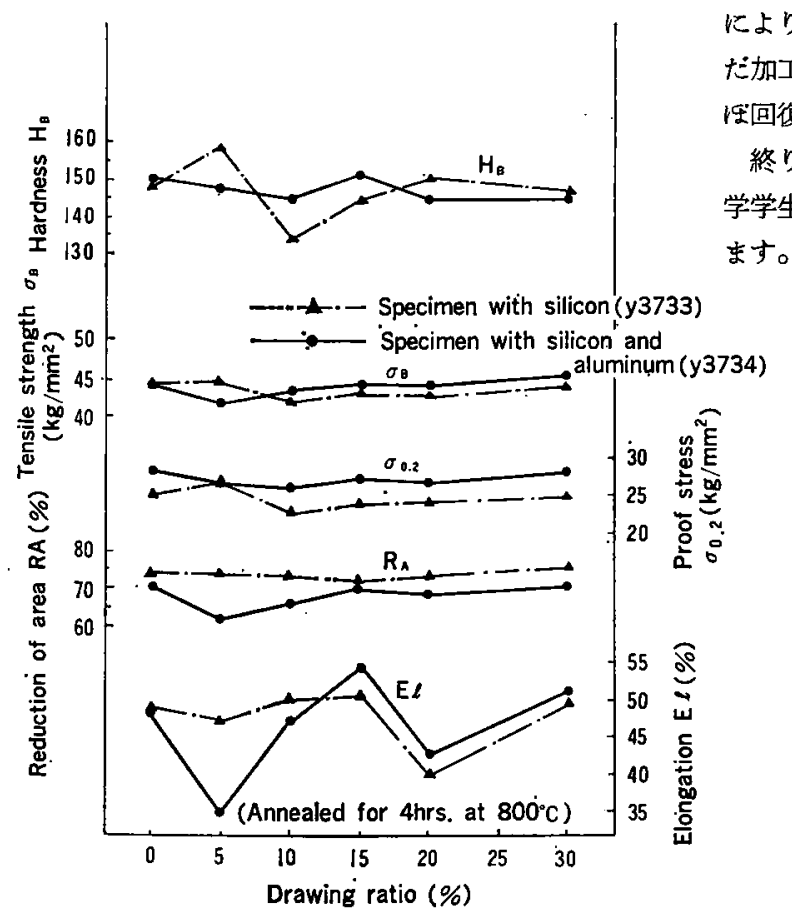

Fig. 12. Relation between mechanical properties after annealing at $800^{\circ} \mathrm{C}$ and drawing ratio.
の状態で, $\mathrm{H}_{\mathrm{B}} 150, \sigma_{\mathrm{B}} 45 \mathrm{~kg} / \mathrm{mm}^{2}, \sigma_{0.2} 25 \mathrm{~kg} / \mathrm{mm}^{2}$, RA 75\%，EI 50\% となっている。

\section{7. 総括および結言}

快削電磁ステンレスについて引抜加工率による特性 の変化について試験を行ない,ミガキ棒としての特性 をほほ把握することができた。その結果をまとめると 次のごとくである。

（1）引抜加工による Hc は急速に增大し， $\mu_{m}$ は急 速に低下して磁性は悪化するが，これを焼鈍すると $600^{\circ} \mathrm{C}$ 程度から再結晶の進行とともに徐々に回復し, $800^{\circ} \mathrm{C}$ 以上の焼鈍において向上を示す。10～15\%のス キンパス領域で結晶の粗大化による磁性向上が見られ ることは既に快削純鉄および 1\%けい素鉄において確 認されている状況と同様である。

(2) アルミニゥム添加試料は全般にわたって磁性が すぐれている。フルミニシム無添加の試料か $900^{\circ} \mathrm{C}$ 焼 鈍において，r相の生成による磁性の劣化を示すのに 対し，フルミニゥム添加試料ではこの現象が見られ ず，磁性は向上を示している。

(3) 機械的性質は良く知られているよ 5 に引报加工 により硬化する。これを焼鈍すると $600^{\circ} \mathrm{C}$ 程度ではま だ加工の影響が残されるか， $700^{\circ} \mathrm{C} の$ 佬鈍によると忹 理回復する。

終りに本研究について熱心绉協力された大同工業大 学学生（現大同興業株式会社）安藤司郎君に感謝致し ます。

\section{（文献）}

1) W.S. Eberly: Iron Age, 183 (1959) April 23, 106

2）加藤，富岡：電気製鎆，37 (1966)，265

3) H. Dietrich : DEW Tech. Berich te, 11 (1971), 42

4）加藤, 関尾, 草加：電気製䤡， 41 (1970), 127

5）加藤, 関尾：電気製鋼，42 (1971)，41

6）加藤，富岡：電気製銅，40 (1969)，296

7）加藤，富岡：電気製鎆，41（1970），51 